\title{
Rancang Bangun Tracking Senjata SS2 Pada Drone Quadcopter S2GA
}

\author{
Aprinda Tri Sugiarto \\ Fakultas Teknik Telekomunikasi militer \\ Program Studi Telekomunikasi \\ Politeknik Angkatan Darat Batu, \\ Malang, Indonesia \\ aprindatris@gmail.com
}

\author{
Nur Rachman Supadmana Muda \\ Fakultas Teknik Telekomunikasi militer \\ Program Studi Telekomunikasi \\ Politeknik Angkatan Darat Batu, \\ Malang, Indonesia \\ Nurrudal@gmail.com
}

\author{
Eko Kuncoro \\ Fakultas Teknik Telekomunikasi militer \\ Program Studi Telekomunikasi \\ Politeknik Angkatan Darat Batu, \\ Malang, Indonesia \\ Ekokoncoro@gmail.com
}

\begin{abstract}
Penggunaan drone pada era industri $4.0 \mathrm{di}$ berbagai bidang sudah sangat berkembang terutama pada bidang militer. Drone S2GA ini merupakan sebuah wahana berbentuk drone yang memiliki kemampuan membawa senjata dan dapat digunakan untuk melumpuhkan musuh di daerah hitam. Pada penembakan senjata dengan drone tingkat akurasi hasil tembakan sangat perlu diperhatikan. Oleh karena itu penelitian ini bertujuan utuk membantu dalam pengenalan sasaran atau target dalam penembakan dengan menggunakan drone Quadcopter S2GA. Pengenalan musuh menggunakan pengolahan citra untuk mendeteksi warna dan mentracking object yang dianggap sebagai target. Penelitian ini menggunakan kamera untuk menangkap gambar, servo untuk menggerakan kamera, arduino untuk mengerakan servo, dan raspberry untuk proses pendeteksian warna dengan python sebagai perangkat lunaknya. Dari hasil percobaan diperoleh hasil $77,8 \%$ terdeteksi sempurna dengan watu di bawah 2.75 detik, hasil 11,1\% terdeksi dengan hasil kurang sempurna dan $11,1 \%$ gagal. Dari hasil penelitian yang di lakukan, pendeteksian yang terbaca dengan jarak di bawah 15 meter terbaca dengan baik. Di atas 25 meter pendeteksian tidak lagi terbaca.
\end{abstract}

\section{Kata Kunci-image prosesing, RGB, quadcopter}

\section{Pendahuluan}

Unmanned Aerial Vehicle (UAV) adalah sebuah wahana berbentuk pesawat terbang yang pengoprasianya tidak menggunakan awak dan penerbangannya dikendalikan dari jarak jauh[1]. Drone adalah sebuah kemajuan teknologi yang sangat berkembang pada era industry 4.0. Penggunaan drone saat ini sudah meliputi berbagai bidang. Seperti dari hal-hal kecil hingga kepentingan yang lebih besar seperti pertahanan dan keamanan [2]. Penggunaan drone pada bidang militer saat ini saat di perlukan untuk sebuah pengintaian dan penghancuran. Drone saat ini di lengkapi senjata untuk penembakannya. Drone penghancur ini digunkan untuk masuk ke daerah lawan, baik membawa bahan peledak maupun senjata. Pada senjata digunkan untuk melumpuhkan serta mengintai musuh.

Pada proses penembakan ada beberapa faktor yang menyebabkan penembakan tidak akurat. Beberapa faktor alam yang menyebabkan penembakan tidak akurat antara lain suhu, kelebaban, endapan ,udara. Adapun faktor yang membuat penembakan tidak akurat yang lain adalah faktor dari manusia itu sendiri yang terbatas kemampuan jarak pandang dan ketahanan tubuh manusia.

Pada perkembangan teknologi saat ini banyak dimanfaatkan untuk memudahkan penguna teknologi dan memaksimalkan teknologi untuk memperbaiki tingkat keakuratan dalam penembakan pada kelemahan yang disebabkan dari manusia itu sendiri. Oleh karena itu pada perkembangan teknologi ini pengolahan citra akan digunakan untuk membantu mendeteksi sasaran untuk meningkatkan akurasi.

Dalam permasalahan ini yang sangat penting adalah mengenali objek untuk diolah mengunakan metode pengolahan citra sebagai sasaran dan melakukan pelacakan terhadap objek tersebut. Setelah mendapatkan sasaran kamera akan mengikuti kemana objek bergerak dengan mengunakan servo. Tanpa adanya pengolahan citra untuk mengenali objek sering terjadi kesalahan yang dilakukan karena operator tidak mengenali target yang dijadikan sasaran. Objek yang dijadikan sasaran berupa warna kemudian diolah untuk membedakan dengan warna yang ada di sekitar sasaran. Hasil dari pengolahan citra tersebut akan mengerakan servo sebagai pengerak untuk mengikuti sasaran.

\section{BAHAN DAN METODE}

Pengolahan citra akan memudahkan operator dalam nenentukan sasaran dengan menampilkan citra dan citra lain yang ada didepannya[3]. Oleh karena itu, penelitian ini dilakukan untuk memudahkan operator Drone dalam mencari dan mengenali musuh dengan citra yang di olah dan di kirimkan dari kamera ke operator dalam bentuk informasi citra. Sebuah penelitian di awali dari perancangan penelitian, percobaan, dan di akhiri oleh pendapatan sebuah hasil dari penelitian.

Dari penelitian ini dapat di jelaskan kamera menangkap sebuah objek warna kemudian di olah menjadi sebuah citra Grayscale atau mengurangi intensitas cahaya menjadi keabu-abuan dari citra tersebut [4]. Dari hasil grayscale maka akan di deteksi warna yang di inginkan. Dari deteksi akan di dapat hasil yang mana jika sesuai akan di lanjutkan dengan Langkah berikutnya penembakan.

Quadcopter adalah pesawat multirotor/multiwing yang mempunyai 4 buah motor. Pada prinsipnya, ketika pesawat ada di udara, ada empat gaya utama yang bekerja di pesawat, $\mathrm{T}$ dorong, drag $\mathrm{D}$, angkat dan berat pesawat (berat $\mathrm{W}$ ). Empat gaya aerodinamis dalam penerbangan. Pada Quadcopter sendiri memiliki empat gerakan dasar yaitu, gerakan sudut (roll, pitch), gerakan altitude (throuttle) dan gerakan sudut. 


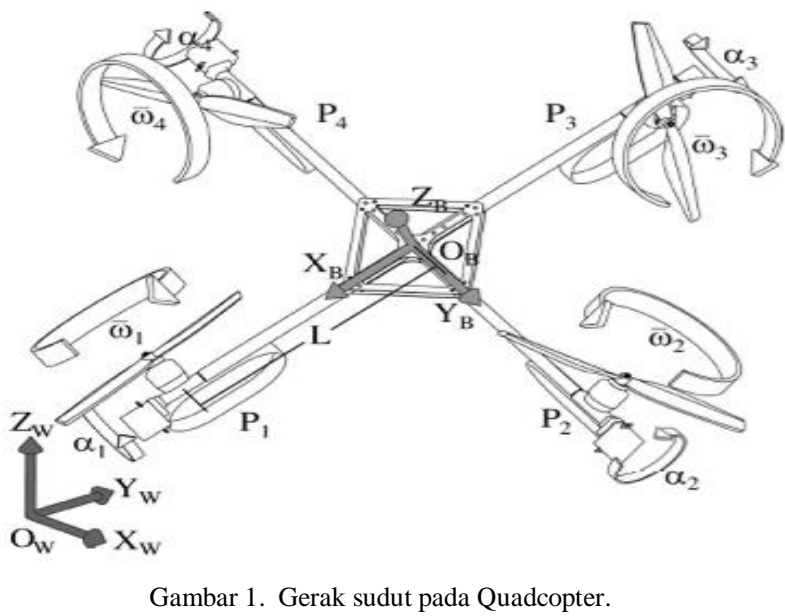

A. Throttle

Throttle adalah gerakan naik dan turunnya drone yang mengatur ketinggian drone dengan mengatur kecepatan semua motor sama besar. Quadcopter itu akan bergerak searah dengan sumbu-z pada koordinat quadcopter sendiri. Jika Throttle di Gerakan ke atas maka akan mengirimkan sinyal untuk memberikan arus yang lebih besar ke motor yang membuat motor akan berputar lebih cepat dan membuat RPM dari motor meningkat sehingga membuat daya dorong motor besar sehingga membuat drone naik. sebaliknya jika di Gerakan ke bawah maka drone akan turun karena gaya dorong dari motor berkurang karena arus yang di berikan berkurang.

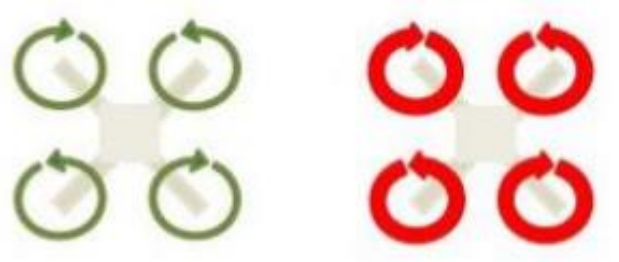

Gambar 2. Gerakan Throttle

\section{B. Roll.}

Roll adalah Gerakan manuver kearah samping kanan atau kiri dari remote dengan meningkatkan kecepatan dari motor yang berputar ke bagian kiri atau kanan quadcopter secara bersama-sama. Karena remote control mengirimkan sinyal untuk memberikan arus ke motor bagian kanan atau ke kiri sehingga drone bergerak ke kanan dan kiri.

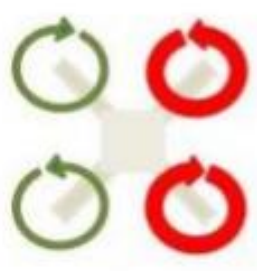

Bend left

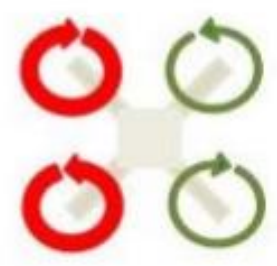

Bend Right
Gambar 3. Gerakan Roll

C. Pitch.

Pitch adalah gerak drone yang hampir mirip dengan gerak drone roll. Pitch adalah gerakan dengan menambah atau menurunkan kecepatan motor bagian depan atau belakang secara bersama dan kecepatan sama[5]. Dalam Gerakan ini drone akan bergerak ke depan dan ke belakang.

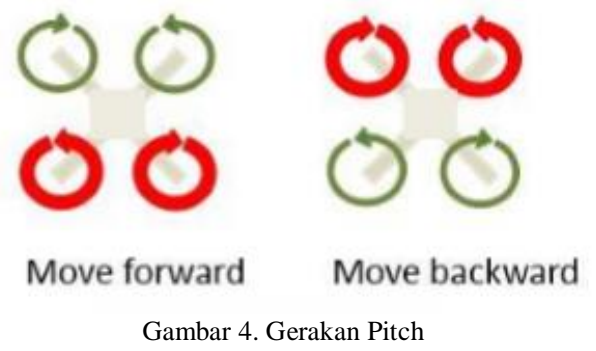

D. Yaw.

Yaw adalah gerakan yang dilakukan dengan menambah kecepatan motor pada posisi yang bersilangan secara bersama-sama menambah kecepatannya. Tujuan gerak ini yaitu untuk mendapatkan manuver quadcopter yang berputar secara searah atau dengan berlawanan pada jarum jam.

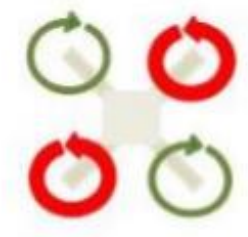

Rotate left

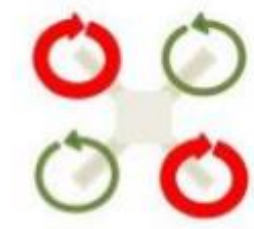

Rotate right
Gambar 5. Gerakan yaw

\section{E. Image Processing}

Image Processing atau pengolahan citra yaitu adalah sebuah disiplin ilmu yang mempelajari tentang teknik-teknik mengolah citra[6]. salah satu proses dengan mengenali suatu karakter atau objek dengan memasukan citra atau sebuah gambar (image). Pada saat ini pengenalan citra sangat berkembang pesat dengan bantuan proses dari komputer untuk mengenali objek untuk memberikan informasi dalam bentuk citra itu sendiri. Input dari pengolahan citra adalah citra sedangkan outputnya adalah hasil dari pengolahan citra.

\section{F. Model Citra.}

Citra yaitu sebuah matrik dua dimensi yang memanfaatkan kecerahan dari sebuah cahaya. Oleh karena itu untuk menuliskan posisi citra sendiri dengan $\mathrm{f}(\mathrm{x}, \mathrm{y})$, yang dimana $\mathrm{f}$ adalah nilai dari koordinat( $\mathrm{x}, \mathrm{y})$.

\section{G. $R G B$.}

RGB ini model ini terdapat 3 komponen yaitu, r, g, b yang merepresentasikan prosentase dari sebuah piksel pada citra digital [7]. Sebuah citra yang berwarna menggunkan model ini (Red, Green, Blue). Ini merupakan intensitas nilai dari sebuah piksel yang terdiri dari nilai merah, nilai biru, dan nilai hijau. Pada derajat kecerahan dengan instensitas piksel ini dinyatakan dalam $\mathrm{R}$ untuk pewarnaan merah. Untuk derajat kecerahan warna hijau yaitu G. Sedangkan derajat kecerahan biru adalah B. 


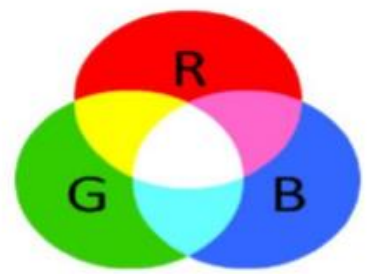

Gambar 6. Warna RGB

\section{H. Grayscale.}

Grayscale adalah citra dengan piksel yang intensitasnya bernilai keabu-abuan.Dalam proses pengolahan citra warna pertama yang di lakukan adalah mengubah warna menjadi Grayscale untuk memudahkan penyederhanaan model citra [8]. Untuk melakukan proses ini layer R, layer G, layer B tetap di perhatikan. Gambar grayscale berbeda dari gambar hitam dan putih, gambar hitam putih hanya gambar dengan dua warna hitam dan putih (juga disebut gambar bilevel atau biner). Gambar abu-abu memiliki banyak nuansa abu-abu di antaranya.

\section{Tracking objek}

Tracking atau melacak objek dapat di artikan suatu kegiatan untuk mengikuti suatu objek. Secara sistem tracking objek adalah suatu kegiatan yang dapat mencari dan mengikuti sebuah objek yang bergerak. Dalam hal ini pelacakan di implementasikan untuk mencari objek dalam bentuk warna. Ada beberapa hal yang membuat pengolahan citra dalam melacak objek terganggu antara lain[9]

- Hilangnya informasi dikarenakan projeksi 3 dimensi dalam citra 2 dimensi.

- Noise yang terjadi pada citra.

- Nonrigid atau artikulasi alami pada objek.

- Objek yang terhalang .

- Bentuk objek yang rumit.

- Perubahan pencahayaan secara drastis.

Persyaratan pengolahaan secara Real-Time.

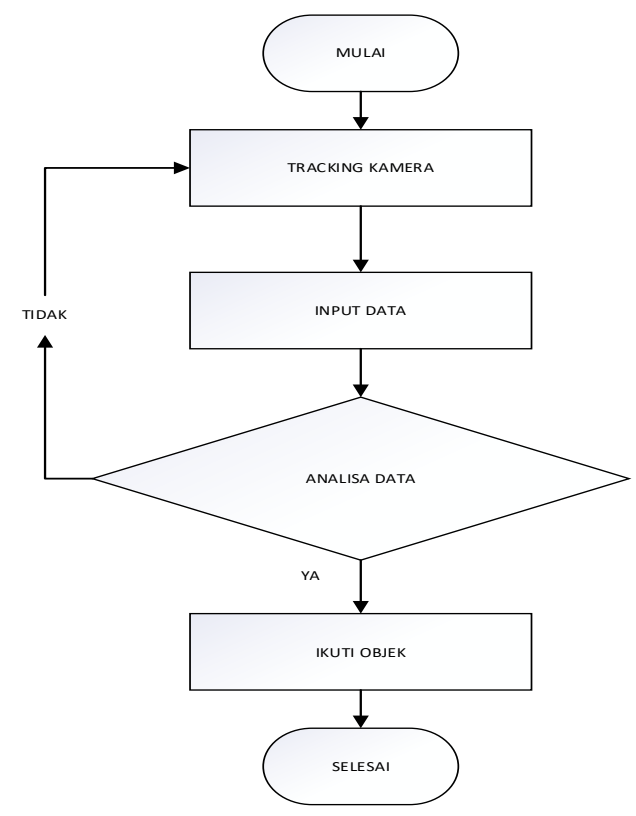

Gambar 7. Diagram alir penelitian.
Dari flowchat di atas menyatakan bahwa analisa data di dapatkan setelah masukan data di terima, kemudian penilaian pengenalan citra di lakukan. Keputusan hasil analisa pengenalan citra tersebut kemudian akan di lanjutkan pada sebuah penembakan ke target atau sasaran yang di anggap sebagai target. Jika pengenalan di anggap tidak sesuai maka akan menunggu inputan Kembali untuk memutuskan pengenalan sebuah citra.

\section{J. Maksimum RBG}

$$
M A K S I M A L=M A X(R, G, B)
$$

Persamaan (1) adalah menentukan nilai makasimum dari variable RGB di masukan ke dalam variable maksimum RGB [10].

Yang dimana :

MAX yaitu adalah nilai maksimum yang bisa di cari dari beberapa angka tersebut.

$\mathrm{R}$ adalah nilai dengan kecerahan warna merah.

$\mathrm{G}$ adalah nilai dengan kecerahan warna hijau.

$\mathrm{B}$ adalah nilai dengan kecerahan warna biru.

\section{K. Minimum $R B G$}

$$
M I N I M A L=M I N(R, G, B)
$$

Sedangkan persamaan (2) untuk menentukan nilai minimum dari variable RGB ke dalam variable minimum RGB.

Yang dimana :

MIN yaitu adalah nilai minimum yang bisa di cari dari beberapa angka tersebut.

$\mathrm{R}$ adalah nilai dengan kecerahan warna merah.

$\mathrm{G}$ adalah nilai dengan kecerahan warna hijau.

$\mathrm{B}$ adalah nilai dengan kecerahan warna biru.

\section{Selisih RBG}

$$
D E L T A=M I X-M I N
$$

Pesamaan (3) adalah persamaan untuk mencari selisih antara nilai maksimal RGB dan minimal RGB dari variable tersebut.

Yang dimana:

MAX yaitu hasil dari nilai maksimum (R,G,B)

MIN yaitu hasil dari nilai maksimum $(\mathrm{R}, \mathrm{G}, \mathrm{B})$ 


\section{HASIl DAN PEMBAHASAN}

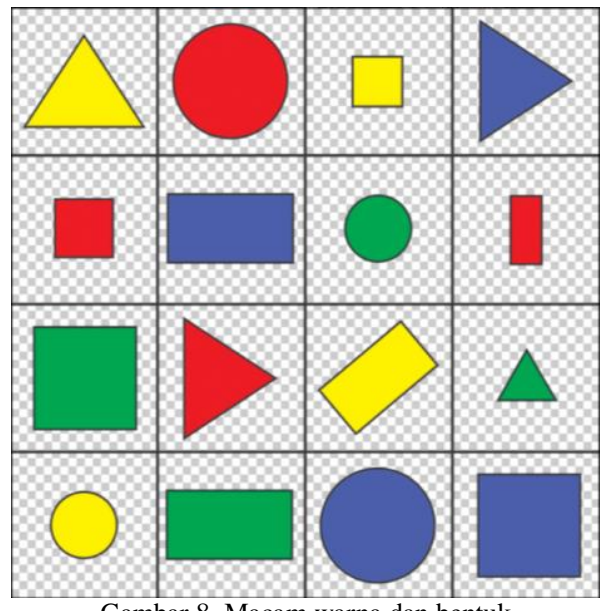

Gambar 8. Macam warna dan bentuk

Pada Gambar 8 adalah input warna yang akan di seleksi menurut warna dari berbagi bentuk. Untuk mendapatkan hasil output yang di inginkan maka warna selain yang sudah di tentukan akan di hilangkan. Pengenalan dengan warna tidak mengenal bentuk hanya mengenal warna yang di tentukan atau di inginkan.

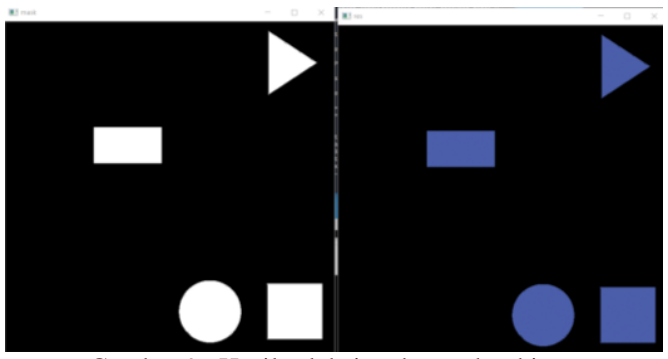

Gambar 9. Hasil seleksi pada gambar biru.

Pada gambar 9 menunjukan hasil seleksi awal pada sebuah gambar yang menunjukan seleksi warna biru. Secara otomatis gambar-gambar yang berwarna biru akan di baca dan di tampilkan lalu di munculkan pada hasil pengolahan citra dengan sebuah gambar. Gambar akan di tentukan nilai RBG dan kemudian merubahnya ke Grayscale atau derajat keabuan.

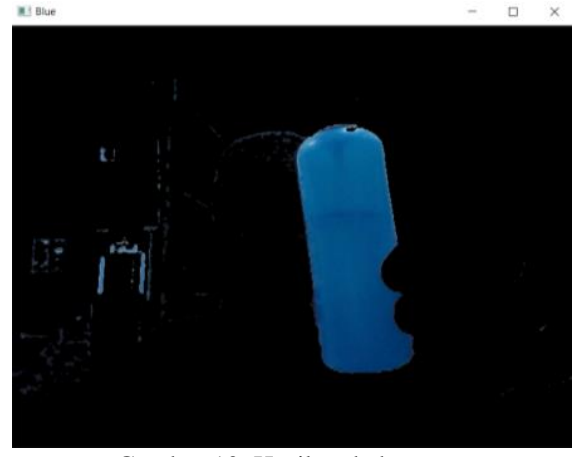

Gambar 10. Hasil pada kamera.

Gambar 10 adalah hasil dari pengolahan citra pada sebuah kamera. Warna yang di munculkan adalah warna biru dengan menghilangkan warna selain biru pada hasil pengolahan citra pada kamera.

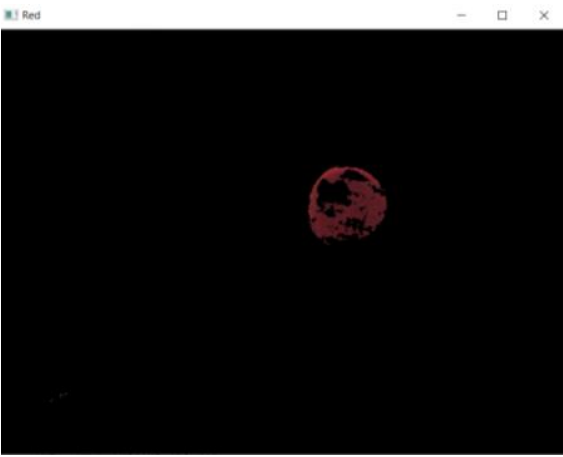

Gambar 11. Hasil pada kamera.

Gambar 11 adalah hasil pengolahan citra warna merah, dengan ini hanya warna merah yang dapat di baca oleh program.

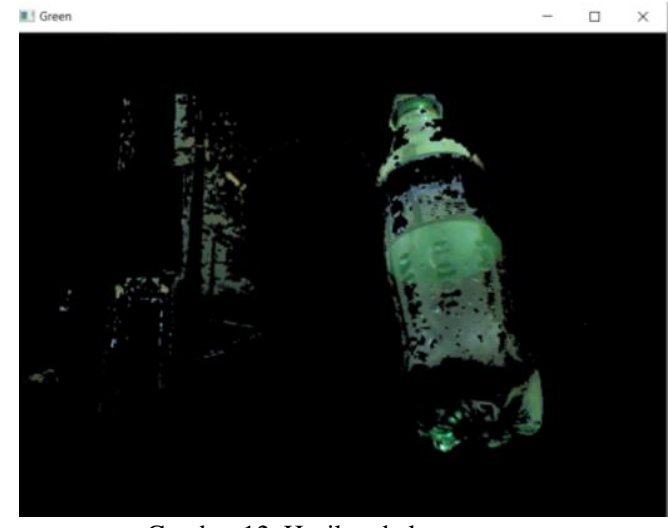

Gambar 12. Hasil pada kamera

Gambar 12 menunjukan hasil pengolahan warna hijau yang di baca dengan menghilangkan warna selain hijau yang di tangkap oleh kamera

\begin{tabular}{|c|c|c|c|c|}
\hline \multirow{2}{*}{ No } & \multirow{2}{*}{ Jarak $(\mathrm{m})$} & \multicolumn{2}{|c|}{ Hasil } & \multirow{2}{*}{ Keterangan } \\
\cline { 3 - 4 } & & Deteksi & Waktu (s) & \\
\hline 1 & 1 & Terdeteksi & 0.89 & Bagus \\
\hline 2 & 4 & Terdeteksi & 0.92 & Bagus \\
\hline 3 & 5 & Terdeteksi & 0.92 & Bagus \\
\hline 4 & 7 & Terdeteksi & 0.98 & Bagus \\
\hline 5 & 10 & Terdeteksi & 1.18 & Bagus \\
\hline 6 & 12 & Terdeteksi & 1.33 & Bagus \\
\hline 7 & 15 & Terdeteksi & 1.97 & Bagus \\
\hline 8 & 20 & Terdeteksi & 2.75 & Kurang \\
\hline 9 & 25 & $\begin{array}{c}\text { Tidak } \\
\text { Terbaca }\end{array}$ & 4.00 & $\begin{array}{c}\text { Tidak } \\
\text { bagus }\end{array}$ \\
\hline
\end{tabular}

hasil $(\%)=\frac{\text { jumlah berhasil bagus }}{\text { jumlah percobaan }} \times 100 \%$

hasil $(\%)=\frac{7}{9} \times 100 \%$

$=77,8 \%$ 
Pengolahan citra dalam percobaan ini menunjukan objek yang bisa di deteksi hanya sejauh 20 meter. Semakin jauh objek maka semakin lama waktu yang diperlukan untuk mengenali objek, hal ini di kerenakan resolusi dan daya tangkap dari kamera tersebut. Semakin besar resolusi dan pixel dari kamera maka semakin lama untuk pemprosesan pengolahan citra karena ada banyak pixel yang harus di olah.

\section{KESIMPULAN}

Dari hasil percobaan didapatkan hasil dengan jarak 1 meter sampai 20 meter objek masih bisa di deteksi dengan waktu di bawah 2,75 detik. Pada jarak 20 meter objek terdeteksi akan tetapi hasil yang didapatkan kurang bagus di sebabkan oleh jarak jangkau kamera sehingga objek terlihat sangat kecil. Jarak 25 meter lebih objek sudah tidak bisa di deteksi karena objek sudah tidak terlihat di kemera. Dari percobaan tersebut juga menunjukan waktu yang diperlukan untuk mengolah citra warna semakin lama jika jarak objek semakin jauh, hal ini disebabkan karena banyaknya warna yang ada di belakang objek. Kualitas kamera juga mempengaruhi kecepatan pengolahan karena semakin besar pixel dari kamera semakin banyak pixel yang harus diolah. Tingkat keberhasilan dari percobaan tersebut adalah $77,8 \%$ terdeteksi dengan bagus dan kegagalan sebesar $11,7 \%$ karena kamera sudah tidak bisa menangkap objek

\section{DAFTAR PUSTAKA}

[1] W. K. Juang and L. L. U. Tung, "Pembuatan Model Quadcopter yang Dapat Mempertahankan Ketinggian Tertentu," J. Tek. Elektro, vol. 9, no. 2, pp. 49-55, 2016, doi: 10.9744/jte.9.2.49-55.

[2] A. Y. Dewi, D. Harinita, and A. Bachtiar, "Korelasi Gaya Angkat dengan Kecepatan Putaran Rotor pada Sistem Pesawat Quadcopter," Tek. Elektro Inst. Teknol. Padang, 2018.

[3] F. T. Industri, "Rancang Bangun Sistem Pelacakan Otomatis Dan Penguncian Sasaran Pada Pertahanan Statis Berbasis Pengolah Citra" 2015.

[4] A. S. Raharjo, A. Saputra, and S. Y. Irianto, "Pengembangan Pengolahan Citra Face Recognition, Face Counting dan Age Gender Detection Secara Real Time di Python," Semin. Nas. Has. Penelit. dan Pengabdi., pp. 68-77, 2019.

[5] K. Hariyanto and D. W. Santoso, "Pengembangan Sistem Penyemprotan pada Platform Pesawat Tanpa Awak Berbasis Quadcoper untuk Membantu Petani Mengurangi Biaya Pertanian dalam Mendorong Konsep Pertanian Pintar (Smart Farming), " $J$. Nas. Teknol. Terap., vol. 1, no. 1, p. 87, 2017, doi: 10.22146/jntt.35168.

[6] D. M. P. Navier-stokes et al., "Pemodelan aliran udara di sekitar sayap pesawat secara 3 dimensi menggunakan persamaan navierstokes," pp. 1-4.

[7] D. A. Prabowo and D. Abdullah, "Deteksi dan Perhitungan Objek Berdasarkan Warna Menggunakan Color Object Tracking," Pseudocode, vol. 5, no. 2, pp. 85-91, 2018, doi: 10.33369/pseudocode.5.2.85-91.

[8] H. Mulyawan, M. Z. H. Samsono, and Setiawardhana, "Identifikasi Dan Tracking Objek Berbasis Image Processing Secara Real Time," Jur. Telekomun. Politek. Elektron. Negeri Surabaya, pp. 1-5, 2011, [Online]. Available: http://repo.pens.ac.id/1324/1/Paper_TA_MBAH.pdf.

[9] Sudaryanto, Mujamilah, Wahyudianingsih, A. Handayani, Ridwan, and A. Mutalib, "Pembuatan Nanopartikel Magnetik Berlapis Polimer Biodegradable dengan Metode Sonokimia," J. Sains Mater. Indones., vol. 8, no. 2, pp. 134-138, 2007.

[10] M. A. Anggriawan, M. Ichwan, and D. B. Utami, "Pengenalan Tingkat Kematangan Tomat Berdasarkan Citra Warna Pada Studi Kasus Pembangunan Sistem Pemilihan Otomatis," J. Tek. Inform. dan Sist. Inf., vol. 3, no. 3, pp. 550-564, 2017, doi: 10.28932/jutisi.v3i3.688. 